A look at the region

\title{
OREA: The Institute for Oriental and European Archaeology, Austrian Academy of Sciences
}

\author{
Barbara Horejs $\mathrm{a}^{\mathrm{a}^{*}}$ \\ ${ }^{a}$ Austrian Academy of Sciences, Institute for Oriental and European Archaeology, Hollandstraße 11-13, A-1020 Vienna, Austria
}

\section{ARTICLE INFO}

\section{Article history:}

Received: $10^{\text {th }}$ April 2018

Accepted: $10^{\text {th }}$ August 2018

DOI: http://dx.doi.org/ 10.24916/iansa.2018.1.7

\section{Key words:}

Orient

Europe

economy

identity

interdisciplinary studies

environment

digital archaeology

\begin{abstract}
A B S TR A C T
The Institute for Oriental and European Archaeology is one of Austria's leading research facilities for archaeological research and covers essential prehistoric and early historical cultural developments from the Near East to Europe. The orient and occident are frequently understood as counterpoints in different worlds and explored separately. In this research institute, these areas are deliberately considered a common cultural bracket for crucial advances of human (pre)history and are therefore explored together. The focus of basic research lies in the time horizon from the Quaternary, about 2.6 million years ago, to the transformation of societies into historical epochs in the first millennium BC.
\end{abstract}

\section{Institutional history}

The Institute for Oriental and European Archaeology (OREA) was founded in 2013 by uniting three longestablished commissions: the Prehistoric Commission, the Commission for Egypt and the Levant and the Mycenaean Commission. The study of the past was one of the main concerns when the Austrian Academy of Sciences was founded in 1847. Accordingly, the "Commission for the promotion of prehistoric research and excavations on Austrian territory“, set up by the Division of Mathematics and Natural Sciences in 1878, is one of the oldest research units of the Academy. The "Egyptian Commission" was founded in 1907 and the "Commission for Mycenaean research" was added significantly later, in 1971. After an international evaluation in autumn 2015, the OREA institute was permanently established at the Austrian Academy of Sciences in June 2016.

*Corresponding author. E-mail: orea@oeaw.ac.at

\section{Institutional structure and facilities}

The OREA research team currently comprises a director, assistant director, sixty-three research staff, four editorial staff, and three administrative staff, with an additional twentyfive affiliated scientists. The Institute houses a subject library with an active acquisition programme, several archives, a lecture room, and seminar room. Additional facilities include a Raw Materials Laboratory and a Digital Archaeology Lab. The Institute also houses the Collection Schachermeyr of Neolithic and Bronze Age ceramics. Fritz Schachermeyr, who was Chair of the Mycenaean Commission from its founding in 1971 until his death in 1987, built an impressive ceramic collection covering the entire eastern Mediterranean. The collection, consisting of around 2000 fragments and some entire ceramic vessels, was donated to the OREA institute to guarantee access to experts for ceramic studies. A permanent exhibition of selected sherds was installed at OREA in 2017 using historic display cases from the Schachermeyr period.

In recent years, the Institute has focused on digitizing archaeological data from older excavations and collections. For 
example, documentation of excavations at the Urnfield Culture site of Thunau-am-Kamp, a fortified hilltop settlement, is almost completely digitized in cooperation between OREA, the county of Lower Austria, and the Austrian Centre for Digital Humanities (ACDH) of the Austrian Academy of Sciences. The extensive analysis and interpretation of the Late Bronze Age cemetery of Franzhausen-Kokoron includes a digital, interactive open-access catalogue, via the Austrian Academy of Sciences Press, with overview plan, basic inventory data, and photographs and drawings of finds and contexts (http://epub.oeaw.ac.at/franzhausenkokoron2/). Material from the cemetery of Inzersdorf forms the basis of a 2017 Masters thesis by M. Fritzl. These efforts also provide a basis for collaboration between research groups, for example between Urnfield Culture Networks and Prehistoric Identities. Various other archive materials, such as the intensive collection of excavation data from Tell el-Dab'a in Egypt, are in process of digitalization and re-organisation for long-term storage and open access presentation in the future (https://www.orea.oeaw.ac.at/ forschung/digital-archaeology/a-puzzle-in-4d/).

\section{Research}

Research methods include archaeological fieldwork (excavations and surveys), material culture studies with diverse archaeometric methods, and interdisciplinary cooperation with a range of different disciplines, including archaeozoology, archaeobotany, anthracology, biological anthropology, palaeogenetics, climatology, geoarchaeology and landscape modelling. The basic analysis and interpretation of early cultures lies at the core of research efforts, which aim to include all possible sources. The study of chronologies, art and early writing as well as a broad socio-cultural spectrum including religion, ideologies and identities compliment research at the institute, with the main foci being:

- Prehistory in the Orient \& Europe.

- Archaeology from the Pleistocene to Early State Societies.

- Environments \& Economies, Digital Archaeology.

- Interdisciplinary Studies of Resources \& Identities.

OREA researchers cover a wide range of disciplines from Prehistoric Archaeology, Egyptology, Sudanese Archaeology, Near/Middle Eastern and early Greek Archaeology to various philologies, Anthropology, Digital Archaeology and Raw Material Studies. In 2018, about 70 OREA researchers are working in 17 countries in Europe and the Near East conducting fieldwork at sites spanning from the Palaeolithic to the Bronze Age.

For ongoing national and international quality assurance as well as additional research funding, the Institute strives for

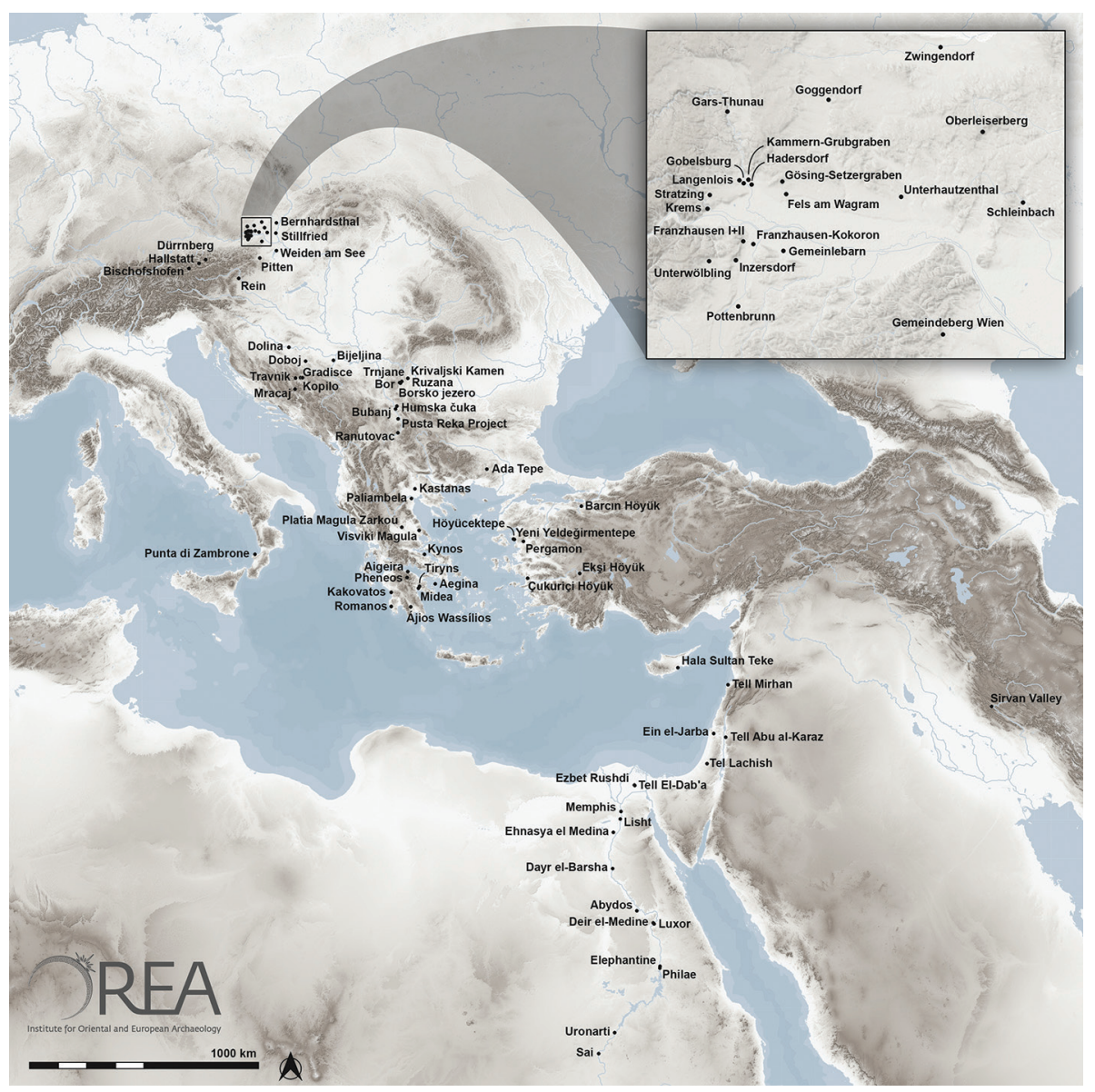

Figure 1. Current research projects at OREA (map: M. Börner/OREA) 
Figure 2. OREA research focus pyramid.

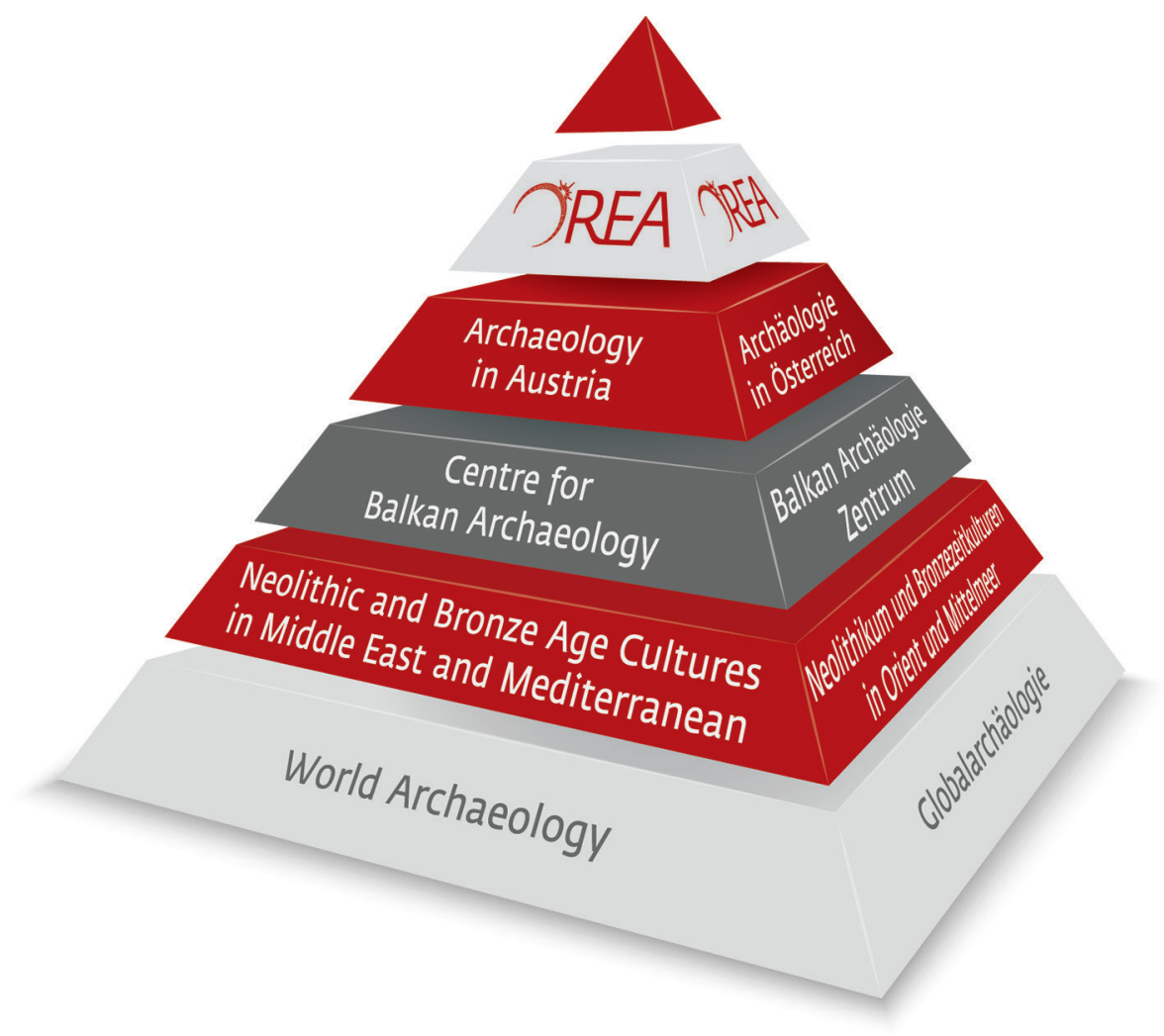

success in competitive external funding. Financial support is provided by the Austrian Science Fund (FWF), the European Research Council (ERC), the EU Marie Curie programme, and INSTAP, as well as by the Austrian National Bank (ÖNB), the White Levy Fund, the City of Vienna, the County of Lower Austria, and various private foundations. OREA is the only archaeological institution in Austria holding highly competitive grants. Altogether four ERC Grants (3 Starting, 1 Advanced) and four FWF START prizes mark OREA as one of the leading institutes in the international field of archaeology.

Targeted research on different priorities is concentrated in research groups spanning broad regions and designed to be trans-regional and diachronic. Research groups are constantly being initiated and developed to pick up new trends in the research landscape and provide new impetus. The following nine research groups are established at OREA as of spring 2018:

Quaternary Archaeology (group leader: Thomas Einwögerer), Anatolian Aegean Prehistoric Phenomena (group leader: Barbara Horejs), Levantine and Egyptian Histories (group leaders: Roman Gundacker and Felix Höflmayer), Material Culture in Egypt \& Nubia (group leader: Bettina Bader), Tell el-Dab'a Publications (coordination: V. Müller), The Mycenaean Aegean (group leader: Birgitta Eder), Mediterranean Economies (group leader: Reinhard Jung), Prehistoric Identities (group leader: Katharina Rebay-Salisbury), UCN Urnfield Culture Networks (group leader: Mario Gavranovic).

\subsection{Quaternary archaeology}

The Quaternary Archaeology research group deals with interdisciplinary research of Palaeolithic societies, from approximately 100,000 years ago to the end of the last glacial period and the gradual settlement in the period up to the sixth millennium BC. The primary focus of the research is in the time between 40,000 and 18,000 years ago, and cultural developments from climatic, ecological and economic perspectives, as well as human-environmental interactions in light of changing resources. In addition to research at well-known sites such as Krems-Wachtberg and Stratzing, the group is involved in research on Gravettian red ochre burials, the Quaternary Archaeology Database Project, and forms the foundation for the Raw Materials Laboratory.

\subsection{Anatolian aegean prehistoric phenomena}

The central theme of the Anatolian Aegean Prehistoric Phenomena (AAPP) group is the holistic analysis of Neolithic, Chalcolithic and Early Bronze Age sites in Anatolia and the Aegean from a supra-regional perspective. This enables a better understanding of phenomena that connected these two major spheres of cultural influence. The AAPP research group unites researchers from both regions and applies interdisciplinary analyses and systematic comparisons in an effort to overcome the different research traditions and orientations of international academic schools. This effort is crucial for understanding causes and socio-cultural impacts. The Balkans as direct contact zones and links to inner Europe are integrated in this broad geographical approach. 


\subsection{Prehistoric identities}

Aspects of prehistoric identities, the building blocks of how people saw themselves and others, include age, sex and gender, descent, social relationships, ethnicity, status and religion. Many of these aspects are inextricably linked to the human body, through which the world is experienced and which is the biological basis of existence. Material culture is directly involved in the creation and maintenance of identities, as well as serving to categorize people. The Prehistoric Identities group works to recreate individual life histories of prehistoric persons with the help of the latest scientific methods that reconstruct stressful events and traumas, health and nutrition, lineages and genetic origin, motherhood and child rearing, and mobility and migration.

\subsection{Levantine and Egyptian histories}

Over the last century, Near Eastern Studies, Biblical Archaeology, and Egyptology have developed individual approaches and specific traditions in addressing the historical questions and specific problems of the pre-classical period of the wider Near East. The Austrian Academy of Sciences is one of the few international research institutions that has developed a multidisciplinary focus on, and an integrative approach to, the history and archaeology of Egypt and the Levant. The Levantine and Egyptian Histories research group aims to consolidate and expand this internationally unique research profile and to continue stimulating and advancing cooperation between Egyptology, Biblical Archaeology, and Near Eastern Studies.

\subsection{Material culture in Egypt and Nubia}

Egyptology remains a text-centred discipline, stressing historical and political interpretations derived from textual sources rather than the material objects used by ancient Egyptians. A discrepancy in theoretical applications exists between archaeological remains that constitute a large portion of ancient Egyptian heritage, and texts in the widest sense. Many of these texts expressed political processes and opinions, written by elite members for a socially restricted group who were able to read. The Material Culture in Egypt and Nubia research group, whilst not ignoring the textual evidence, focuses on the evidence from 'things' in order to compare artefacts with source groups transmitting political aspects. In this way, differences and similarities of these source types will be highlighted and more information on social and cultural processes obtained.

\subsection{Tell el-Dab'a publications}

The central theme of the Tell el-Dab'a Publications group is the synoptic analysis and final publication of the Tell elDab'a excavations carried out under the direction of $\mathrm{M}$. Bietak from 1966 to 2009. Based on the publication concept developed in 2014, in particular a cooperation agreement with the Austrian Archaeological Institute, members of this research group concentrate on specific topics of the excavations at ancient Avaris, the modern Tell el-Dab'a.

\subsection{The Mycenaean Aegean}

The Mycenaean Aegean research group takes up the long and strong tradition of the ÖAW Aegean \& Anatolian section on the Bronze Age palace and text cultures of the second millennium in the Aegean. The group brings together all ongoing larger and smaller projects dealing with different aspects of the Mycenaean culture and the Middle Bronze Age (Minoan Crete, Central European mainland), including projects on the political structures of Mycenaean Greece and its political geography, the genesis and transformations of Bronze Age Aegean cultures, the northern and western regions of Mycenaean Greece, relations between the Greek mainland and Crete during the Late Bronze Age, written testimonies of Linear B-boards, Mycenaean religious practice and rituals, and Middle Helladic and early Mycenaean burials and graves. The geographical area covers all areas of the Mycenaean culture from Thessaly to Crete and from the Ionian Islands to the Dodecanese and the coast of Asia Minor from Miletus to Halicarnassus.

\subsection{Mediterranean economies}

A central aspect of the Mediterranean Economies research group projects is the notion that the development of the forces of production constitutes a decisive factor in the development of economic and political structures of all social systems, and therefore also determines contacts between societies to a large extent. Therefore, modes of production and property as well as exchange relationships between different Mediterranean societies form the basis of the different research programmes. For the potential of this approach to be carried out requires close interdisciplinary cooperation of archaeologists with colleagues from a wide range of disciplines in the humanities and natural sciences. In addition to the archaeological evidence, written sources are an important part of this research.

\subsection{Urnfield culture networks}

The Urnfield Culture Networks (UCN) is a broad-based competence centre of researchers from different regions integrated in a common network. UCN connects existing, large projects conducted over several years with current research questions regarding the period from 1300 to 800 BC (Urnfield Culture, Late Bronze Age/Early Iron Age). The network involves archaeologists from central and southeast Europe and covers a wide range of topics, including material culture, burial, and ritual. It is therefore an ideal research base for junior and senior researchers from Austria and abroad.

\subsection{Enigma of Hyksos project}

In addition to the aforementioned Research Groups, The Enigma of Hyksos project, led by Manfred Bietak, examines the Hyksos, a dynasty of foreign rulers in power in Egypt between c.1640 and 1530 BC. Their exact geographical origin in the Levant, the process of their seizure of power in Egypt, and their role in history remains an enigma, as the period is poorly represented in texts. Despite this dearth of textual data, the Hyksos phenomenon has mainly 
been studied within text-based Egyptology, ignoring other possible sources such as archaeological remains, burial customs, settlement patterns, and biological data. Combining new data from recent excavations at several places in Egypt's eastern Delta with finds stored in several museums around the world, scholars can now examine enormous quantities of objects reflecting the material culture and physical remains attributable to the carriers of the Hyksos rule and their predecessors. The Enigma of Hyksos project is conducted in eight interrelated research tracks, incorporating archaeological analyses, cultural interference studies, new onomastic studies, bioarchaeology (ancient DNA and strontium isotopes), and gas-phase chromatography. The aim of this interdisciplinary project is to reveal the origin of the western Asiatic population, the dialogue with the host country, the impact on the culture of the latter and finally their heritage in Egypt.

\section{Publication strategy}

The institutes' strategy covers two different fields of publication: OREA's own publication series and external international publications of OREA scientists. The institute publishes two international journals and five publication series. All series and journals edited and published by OREA are internationally peerreviewed and follow high state-of-the-art standards for scientific publications, regularly monitored by the Austrian Academy of Sciences and its publishing house as well as by international ranking institutions (Thomson Reuters, ERIH).
Figure 3. Publication series of OREA with recent volumes (layout: A. Schwab/OREA).
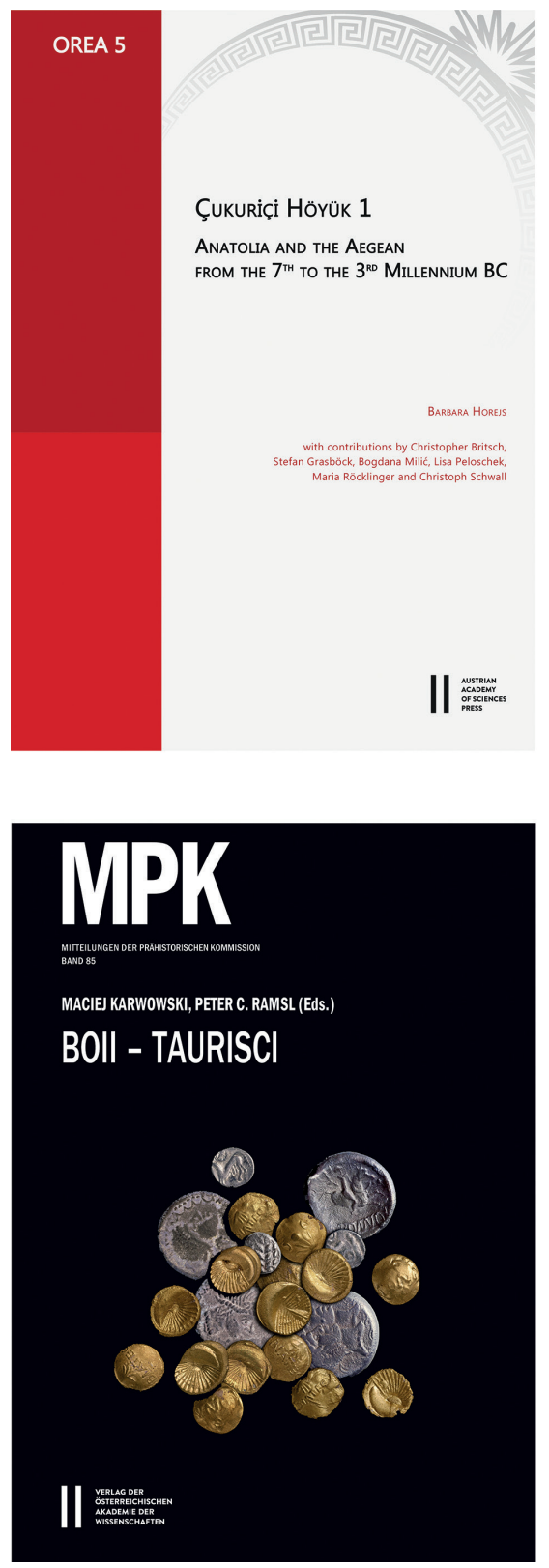
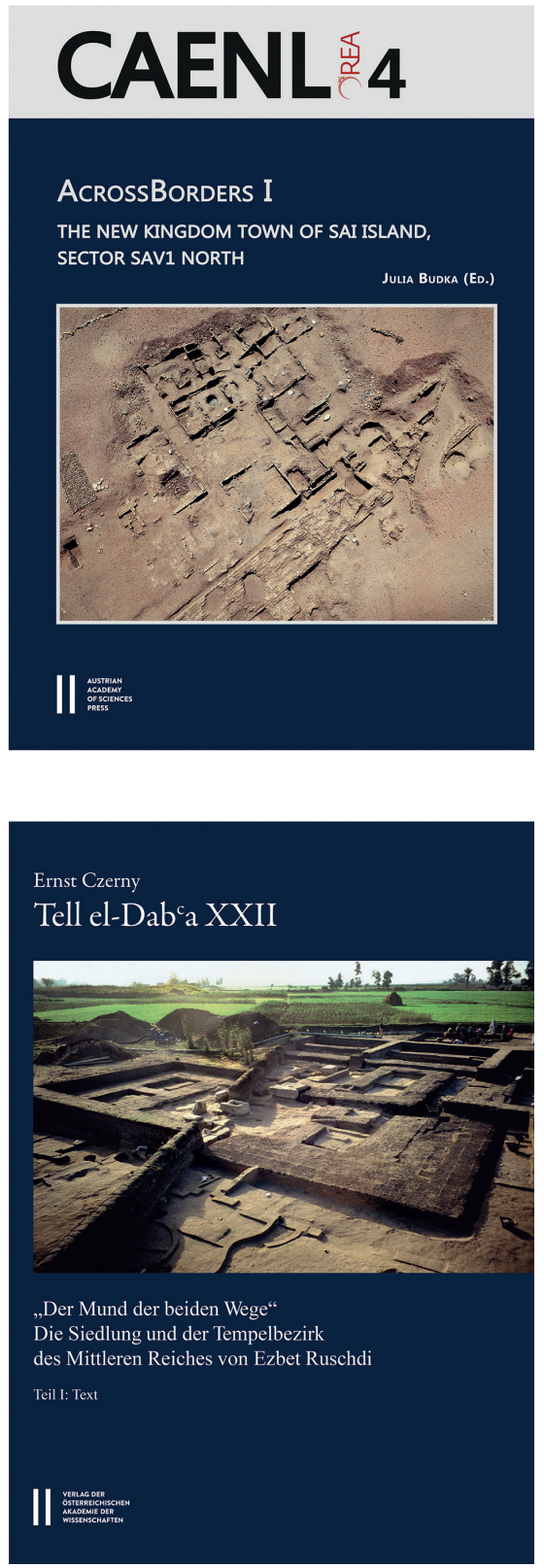


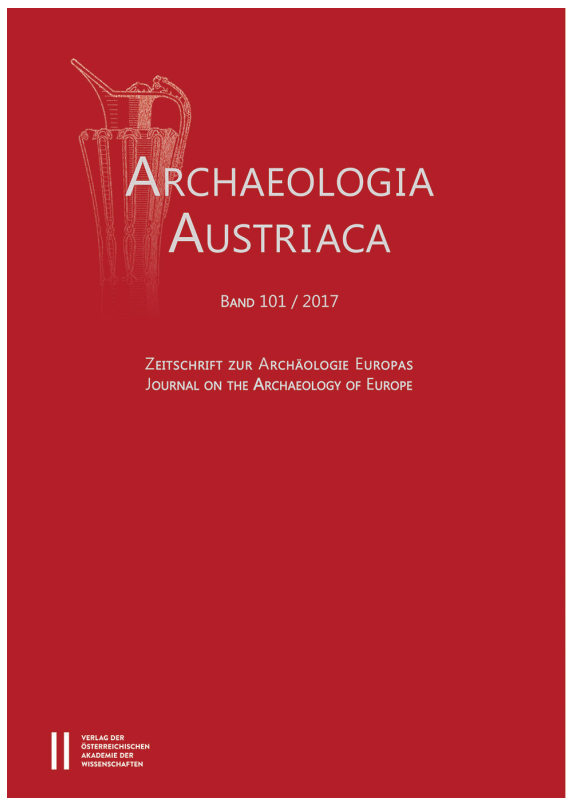

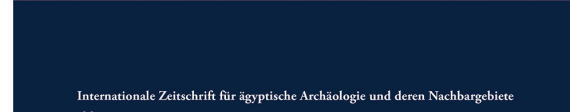

ÄGYPTEN UND LEVANTE

कालितो

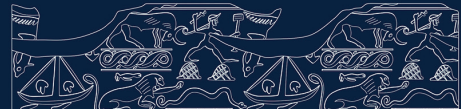

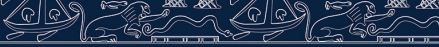

EGYPT AND THE LEVANT

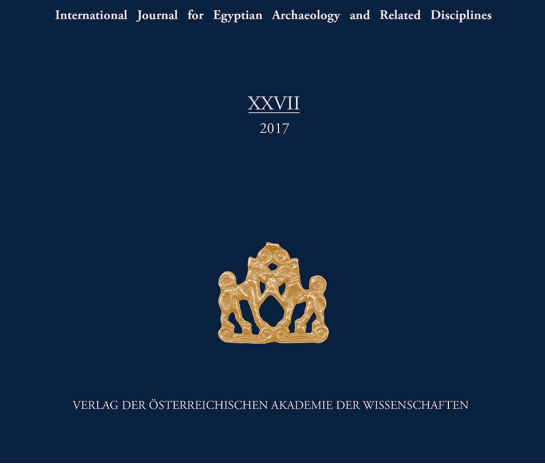

Figure 4. The two internationally ranked journals with recent volumes (layout: A Schwab/OREA).

\section{Series}

OREA Oriental and European Archaeology

CAENL Contributions to the Archaeology of Egypt, Nubia and the Levant UZK Studies of the Cairo branch of the Austrian Archaeological Institute

MPK Mitteilungen der Prähistorischen Kommission (Communications of the Prehistoric Commission)

MykStud Mykenische Studien (Mycenaean Studies)

\section{Journals}

Ägypten und Levante / Egypt and the Levant

International Journal of Egyptian Archaeology and Related Disciplines Archaeologia Austriaca

International Journal on the Archaeology of Europe

\section{Selected Publications by OREA members from 2017}

ALRAM-STERN, E., 2017. Die chalkolithischen Statuetten von ÄginaKolonna. Jahreshefte des Österreichischen Archäologischen Instituts, 85, 2016, 7-56.

ANDRESON, W., HOPPER, K., ROBINSON, A., eds., 2017. Landscape Archaeology in Southern Caucasia. Finding Common Ground in Diverse Environments. Proceedings of the workshop held at $10^{\text {th }}$ ICAANE in Vienna, April 2016. Oriental and European Archaeology 8. Vienna: ÖAW. BUDKA, J., 2017. AcrossBorders I. The New Kingdom Town of Sai Island, Sector SAV1 North. Contributions to the Archaeology of Egypt, Nubia and the Levant 4. Vienna: ÖAW.

BURKE, A.A., PEILSTÖCKER, M., KAROLl, A.B., PIERCE, G.A., KOWALSKI, K., BEN-MARZOUK, N., DAMM, J.C., DANIELSON, A.J., FESSLER, H.D., KAUFMAN, B., PIERCE, K.V.L., HÖFLMAYER, F., DAMIATA, B.N. and DEE, M.W., 2017. Excavations of the New Kingdom Fortress in Jaffa, 2011-2014. Traces of Resistance to Egyptian Rule in Canaan. American Journal of Archaeology, 121, 85-133.

FISCHER, P.M. and BÜRGE, T., eds., 2017. 'Sea Peoples' Up-to-Date. New Research on Transformations in the Eastern Mediterranean in the $13^{\text {th }}-11^{\text {th }}$ Centuries BCE. Contributions to the Chronology of the Eastern Mediterranean, 35. Vienna: ÖAW.

GUNDACKER, R., 2017. Papyrus British Museum 10056. Ergebnisse einer Neukollationierung und Anmerkungen zur inhaltlichen Auswertung im Rahmen der militärischen Ausbildung Amenophis' II. Egypt and Levant, $27,281-334$.

HAAG, S., HOREJS, B., POPOV, H. and PLATTNER, G., eds., 2017. Das erste Gold. Ada Tepe. Das älteste Goldbergwerk Europas. Eine Ausstellung des Kunsthistorischen Museums Wien in Kooperation mit dem Nationalen Archäologischen Institut mit Museum der Bulgarischen
Akademie der Wissenschaften, Sofia (NAIM), und dem Institut für Orientalische und Europäische Archäologie der Österreichischen Akademie der Wissenschaften (OREA). Vienna.

HÖFLMAYER, F., 2017. A Radiocarbon Chronology for the Middle Bronze Age Southern Levant. Journal of Ancient Egyptian Interconnections, 13, $20-33$

HOREJS, B., 2017. Çukuriçi Höyük 1. Anatolia and the Aegean form the $7^{\text {th }}$ to the $3^{\text {rd }}$ Millennium BC. Oriental and European Archaeology, 5. Vienna: ÖAW.

HOREJS, B., 2017. Zum Alltagsleben der Ada Tepe Goldproduzenten im 15. Jh. v. Chr. Das Fundensemble aus Haus 7 in funktionaler und kontextueller Analyse. Archaeologia Austriaca, 101, 205-268.

HOREJS, B. and SCHWALL, Ch., 2018. Interaction as a stimulus? Cukurici Höyük and the transition from the Late Chalcolithic period to the Early Bronze Age in Western Anatolia. In: S. Dietz, F. Mavridis, Ž. Tankosić, and T. Takaoğlu, eds. Communities in Transition: The Circum-Aegean Area in the $5^{\text {th }}$ and $4^{\text {th }}$ Millennia BC. Oxford: Oxbow, 530-537.

JUNG, R., ALEXANDROV, S., BOZHINOVA, E. and MOMMSEN, H. (with an appendix by HEIN, A. and KILIKOGLOU, V.), 2017. Mykenische Keramik in der Rhodopenregion. Herkunft, regionaler Kontext und sozioökonomische Grundlagen. Archaeologia Austriaca 101, 269-302.

MEYER-HEINTZE, S., SPRAFKE, T., SCHULTE, P., TERHORST, B., LOMAX, J., FUCHS, M., LEHMKUHL, F., NEUGEBAUERMARESCH, C., EINWÖGERER, T., HÄNDEL, M., SIMON, U. and SOLÍS-CASTILLO, B., 2017. The MIS $3 / 2$ transition in a new loess profile at Krems-Wachtberg East. A multi-methodological approach. Quaternary International, 464(B), 370-385.

POPOV, H. KOLEVA, M., ANDONOVA, A, DIMITROVA, J. and VĂLČEV, I., 2017. Das Goldbergwerk auf dem Ada Tepe. Zu Topografie, Stratigrafie, Chronologie und Interpretation des Nordareals. Archaeologia Austriaca, 101, 161-204

REBAY-SALISBURY, K., 2017. Breast is best - and are there alternatives? Feeding babies and young children in prehistoric Europe, Mitteilungen der Anthropologischen Gesellschaft in Wien, 147, 13-29.

REBAY-SALISBURY, K., 2017. Rediscovering the body: cremation and inhumation in early Iron Age Central Europe. In: J.I. Cerezo-Román, A. Wessman and H. Williams, eds. Cremation and the Archaeology of Death. Oxford: Oxford University Press, 52-71.

REBAY-SALISBURY, K., 2017. Bronze Age beginnings: the conceptualisation of motherhood in prehistoric Europe. In: D. Cooper and C. Phelan, eds. Motherhood in Antiquity. New York: Palgrave Macmillan, 169-196.

SCHWALL, Ch., 2017. Cukuriçi Höyük 2. Das 5. und 4. Jahrtausend v. Chr. 
in Westanatolien und der Ostägäis. Oriental and European Archaeology, 7, Vienna: ÖAW.

WILCZAK, C.A., MARIOTTI, V., PANY-KUCERA, D., VILLOTTE, S. and HENDERSON, C.Y., 2017. Training and interobserver reliability in qualitative scoring of skeletal samples. Journal of Archaeological Science, Reports, 11, 69-79.

\section{Follow the OREA Institute:}

facebook.com/OREAnews/

twitter.com/orea_news

www.orea.oeaw.ac.at

\section{Barbara Horejs - a scientific profile}

Barbara Horejs, director of OREA since its establishment, studied Prehistory and Protohistory as well as Classical Archaeology at the Universities of Vienna, Athens and Berlin. She took a $\mathrm{PhD}$ in Prehistoric Archaeology from the Freie Universität Berlin in 2005 and became Honorary Professor at the University in Tübingen 2015. She was awarded an FWF START grant in 2010 and an ERC Starting Grant in 2011 for
"Prehistoric Anatolia". From 2011-2012, she was Director of the Young Curia of the Austrian Academy of Sciences (ÖAW), and since 2015 Corresponding Member of the Division of Humanities and the Social Sciences of the Austrian Academy of Sciences, as well as being Corresponding Member of the German Archaeological Institute (DAI) since 2016. She is (Co-)Editor of the journal Archaeologia Austriaca and the monograph series Mitteilungen der Prähistorischen Kommission (MPK), Mykenische Studien, and Oriental and European Archaeology (OREA). Her primary research interests are Prehistoric archaeology and Landscape archaeology in south-eastern Europe, the Aegean, and Anatolia; the Neolithic, Chalcolithic and Bronze Age, including the advanced civilizations of Late Bronze Age; the intersections of different cultural areas, knowledge transfer and communication networks; and the relative and absolute chronologies between the Danube Region and Anatolia. She became Director of the Institute for Oriental and European Archaeology (OREA) at the Austrian Academy of Sciences, Vienna in 2013.
Prof. Dr. Barbara Horejs

Director OREA

Hollandstrasse 11-13, 1020 Vienna

barbara.horejs(at)oeaw.ac.at

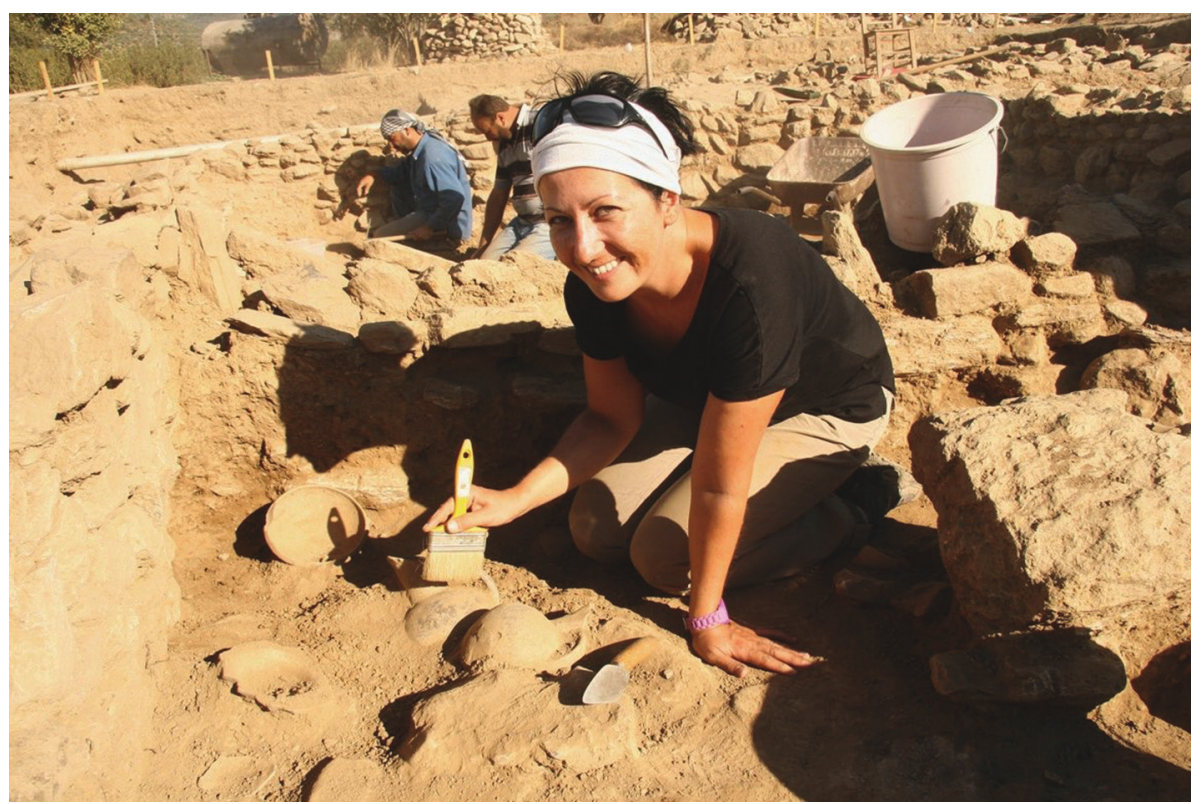


